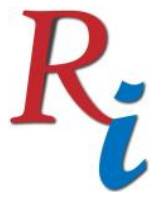

Asia Proceedings of Social Sciences

(APSS)

www.readersinsight.net/APSS

\title{
Political MARKETING FACTORS THAT AFFECT Voting INTENTION ON INDONESIAN 2019 ELECTION
}

\author{
Marina Wamilia*
}

Master Management Program Student IPB University

Indonesia

\section{Jono M. Munandar}

Master Management Program Lecturer IPB University

Indonesia

\section{Ujang Sumarwan}

Master Management Program Lecturer IPB University

Indonesia

*Corrosponding author's Email: marinawamilia@gmail.com

Peer-review under responsibility of 5 th $^{d}$ Asia International Conference 2019Scientific Committee http://connectingasia.org/scientific-committee/

(C) 2019 Published by Readers Insight Publisher, lat 306 Savoy Residencia, Block 3 F11/1,44000 Islamabad. Pakistan,

editor@readersinsight.net

This is an open access article under the CC BY-NC-ND license (http://creativecommons.org/licenses/by-nc-nd/4.0/). 


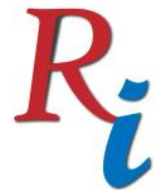

\section{Asia Proceedings of Social Sciences}

(APSS)

www.readersinsight.net/APSS

\section{A b s tract}

Indonesia will face the biggest democratic party, the presidential election in 2019. There are two candidates, Number 01 (Joko Widodo-Ma'ruf Amin) and Number 02(Prabowo SubiantoSandiaga Uno). Increasing the number of voters from previous elections will certainly be a challenge for each candidate to win the hearts of the people with a political marketing approach that is by understanding the characteristics and behavior of the people in decision making. The purpose of this study is to identify the factors that influence voter perceptions in Java Island regarding the situation of presidential election 2019. Candidates conducted political marketing approach by doing research to understand the perception of voters. The data retrieval method is quota sampling technique. Data was collected using an online questionnaire with the object of respondents are Indonesian citizens, domiciled in Java Island and have voting rights in presidential election 2019. The processing and analysis of data uses logistic regression analysis with SPSS (Statistical Package for the Social Sciences) version 23. Statistical test results show that voter perception based on price, leadership, agricultural orientation, positioning and the decision to choose electronic Customer Relationship Management approach (pre-purchase aspect and at-purchase aspect) significant effect on the chosen candidate.

\section{Rese a r ch H igh I ight s}

(Firmanzah, 2012) suggests political marketing is a strategic action performed by candidates for voting voters in the elections. Briefly the higher the competition in the political world requires a certain strategy to win the competition. The political marketing strategy helped the rigorous competition process for the candidate and its expatriate political party to compete with voters. (Alie, 2013)suggests that the awareness of political actors in the importance of political marketing in the political world is increasingly strong.

Percentage of the largest number of voters in Java Island is $56.6 \%$. This can be interpreted if The President and Vice Presidents candidates is able to get support from all voters in Java Island, then it is confirmed the candidate can win the election of 2019. The President and Vice Presidents candidates should be aware of the factors influencing the decision to elect a 


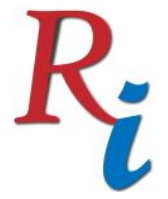

\section{Asia Proceedings of Social Sciences}

(APSS)

www.readersinsight.net/APSS

President and Vice Presidents candidates in Java Islands to determine an effective strategy for voting voters on Java Island.

Voter's participation in Java Island is always increasing on each of its periods (2004, 2009 and 2014). Voters in Java Island can be a big market share for presidential and vice president candidate. The purpose of this study is to identify the factors that influence consumer perceptions in Java Island regarding the situation of presidential election 2019. The research is expected to provide suggestions for candidates to develop political strategies and to know what the voters consider in deciding to choose a candidate.

\section{Graphical A bstract}

The research model of operational variables is shown in Figure that was created by the researcher before testing the structural model.

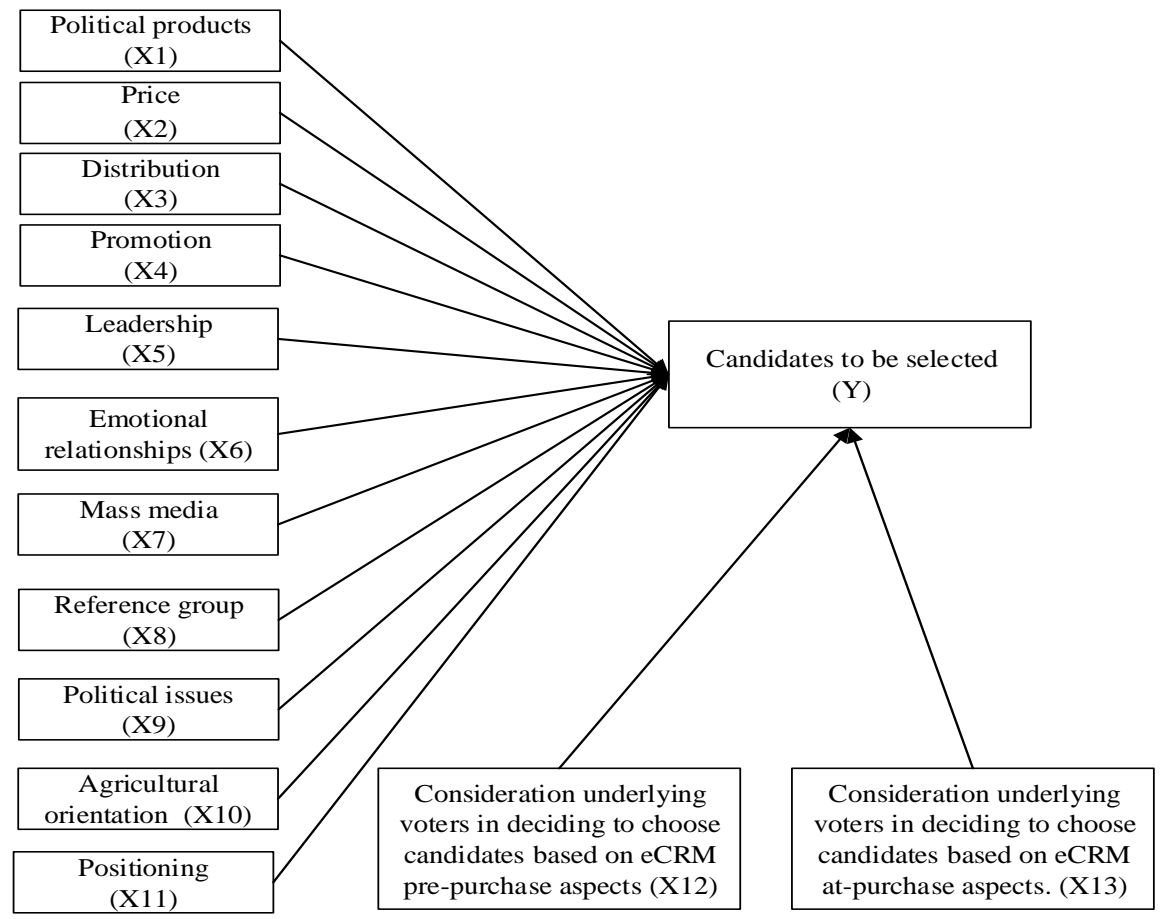

\section{Research Objectives}

The purpose of this study is to identify the factors that influence consumer perceptions in Java Island regarding the situation of presidential election 2019. Candidates conducted 


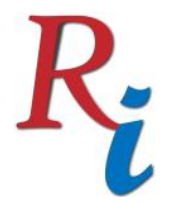

\section{Asia Proceedings of Social Sciences}

(APSS)

www.readersinsight.net/APSS

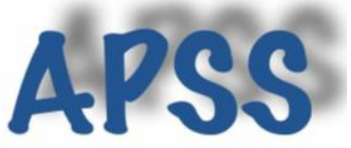

political marketing approach by doing research to understand the perception of consumers. The data retrieval method is quota sampling technique. Data was collected using an online questionnaire with the object of respondents are Indonesian citizens, domiciled in Java Island and have voting rights in presidential election 2019. Independent variables to be researched are consumer perceptions based on product, price, distribution, promotion, leadership, emotional relations, mass media, reference group, political issue, agricultural orientation, positioning and the decision to choose electronic Customer Relationship Management approach (pre-purchase aspect and at-purchase aspect). The dependent variables to be researched are candidate to be chosen. The processing and analysis of data uses logistic regression analysis with SPSS (Statistical Package for the Social Sciences) version 23. Statistical test results show that consumer perception based on price, leadership, agricultural orientation, positioning and the decision to choose electronic Customer Relationship Management approach (pre-purchase aspect and at-purchase aspect) significant effect on the chosen candidate.

\section{Methodology}

The design of the research used is case studies. This research uses a quantitative approach in the form of researched variables. Research uses the method of collecting survey data with questionnaire. Filling questionnaire is done directly and online. The respondents were taken with the quota sampling technique. The respondent in the study is people with the provisions of the Indonesian citizen, domiciled in Java Island, meets the minimum age requirement of 17 years, had voting rights in the elections 2019 and access to the internet. The study used a sample number of 462 respondents. Responders are performed with the technique quota sampling by looking at the number of voters in each province of Java namely DKI Jakarta (7.01\%), Banten (7.33\%), West Java (30.06\%), East Java (27.93\%), Central Java (25.20\%) and DI Yogyakarta (2.47\%). The data analysis methods used in this study is descriptive analysis method and logistical regression analysis. Descriptive analysis is used to identify the characteristics of the voters in Java Island and linear regression analyses used to analyze the voter's knowledge of factors influencing the decision to elect presidential candidates. Data processing using Microsoft office excel software and SPSS software version 23. Data obtained is qualitative and quantitative data. 


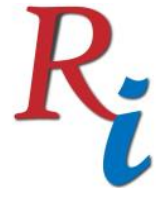

\section{Asia Proceedings of Social Sciences}

(APSS)

www.readersinsight.net/APSS

\section{Results}

Statistical analysis with SPSS (Statistical Package for the Social Sciences) version 23 results show that voter perception based on price factors relating to the cost of the campaign, leadership related to the ability and personality of candidate, agricultural orientation related to agricultural infrastructure, positioning related to the solutions offered candidate, decision to choose eCRM approach candidate of pre-purchase aspects is getting information easy and promotion/ campaign attractiveness, and decision to choose eCRM approach candidate of atpurchase aspects is the elections that feel safe and confidential significant effect on the chosen candidate. So it can be concluded that the respondent already has a decision to vote.

\section{Findings}

In general, the characteristics of the respondents who became the object of this study were relatively balanced, the percentage of female respondents was $55,41 \%$ followed by a percentage of male respondents of $44,59 \%$. The age range of 17-25 years are dominates respondents with unmarried marital status, as well as the majority of Islamic respondents. The majority of respondents have attended college education, the status and profession of the most dominant occupations as students. The average reception of respondents in a month $\leq$ Rp. 1,5 million with the frequency of participation of respondents in the most dominant presidential election is more than twice.

\section{References}

Alie. (2013). Pemasaran Politik di Era Multipartai. Jakarta (ID): Expose.

Firmanzah. (2012). Marketing Politik Antara Pemahaman dan Realitas. Jakarta (ID):

Yayasan Pustaka Obor Indonesia.

Munandar. (2014). Elektabilitas calon presiden yang berorientasi pertanian (Jelang pilpres 9 Juli 2014). Bogor (ID): IPB.

Sumarwan. (2015). Perilaku Konsumen: Teori dan Penerapannya dalam Pemasaran edisi kedua. Bogor (ID): Ghalia Indonesia. 